\title{
Competition in Marketing: Survival Yardstick for Small and Medium Enterprises (SMEs) in Nigeria
}

\author{
Olanrewaju Samson Ibidunni \\ Covenant University, Ogun-state, Nigeria \\ Ogundeji J. K. Ogundele \\ Lagos State University, Lagos, Nigeria
}

\begin{abstract}
The topic investigated competition in marketing as a survival yardstick for small and medium enterprises (SMEs) in Nigeria. The objectives addressed by this study were: (1) identifying different types and intensity of competition that SMEs are exposed to along the life-cycle portfolio in Nigeria; (2) quantifying the strength of SMEs vis-à-vis some foreign enterprises in terms of market competition; and (3) proffering solutions on how best they could match competitively these foreign enterprises. Relevant models and theories were employed in literature to evolve detailed analysis of issues relating to the variables used in terms of competition in marketing and survival of juice-producing SMEs. Two hypotheses were investigated through the survey of 20 prominent Ikeja based SMEs using Cluster sampling, 5-points Likert summated rating scale was adopted, while Yard's formula with 95\% confidence level and $5 \%$ error tolerance was used. Alternative form validity of the instrument was measured at 0.63 while its reliability was measured at Cronbach’s alpha of 0.70. Pearson’s product-moment correlation was used in testing hypothesis 1 while standard multiple regressions were used to test hypothesis 2. Findings revealed that there was strong relationship between survival of juice-producing SMEs with forms of competition on a firm's life-cycle; while competition had positive effects on survival components for the enterprises. It was concluded that since competition subsists in any firm's life-cycle, strategies to support operations for survival must be adopted. It was recommended that operators of SMEs have to monitor and manage competition as it affects their businesses positively and/or negatively.
\end{abstract}

Keywords: competition, firms' life-cycle, survival of enterprises, strategies to support operations, operators of small and medium enterprises (SMEs), monitor and manage competition

\section{Introduction/Background to the Study}

Today’s business in any industry in Nigeria is multi-dimensional. According to Okaka (1990), Ogundele and Opeifa (2004), Ogujiuba, Ohuche, and Adenuga (2004), Ogundele (2007), forms of small and medium enterprises (SMEs) include retailing, wholesaling, servicing, agriculture, and extractive activities in mining and lumbering. Competition remains a programme to participate in and manage effectively within Nigerian

Olanrewaju Samson Ibidunni, Ph.D., Department of Business Management, Covenant University.

Ogundeji J. K. Ogundele, Ph.D., Department of Business Administration and Management Technology, Lagos State University.

Correspondence concerning this article should be addressed to Olanrewaju Samson Ibidunni, Department of Business Management, Covenant University, Canaanland, Ota, Ogun State, Nigeria. E-mail: samsonibidunning@yahoo.com; samson.ibidunni@covenantuniversity.edu.ng. 
business environment in order for SMEs to achieve stated and anticipated goals and objectives. With the strength of multinational enterprises operating also, SMEs in Nigeria have not found it easy facing the fierce competition, hence numerous of them die prematurely. Prior to Nigeria's independence in 1960, multinational enterprises, with the spread of their subsidiaries and other allies, have dominated almost all facets of business in the country. The adoption and usage of improved technology, coupled with the financial and managerial supports from the parent companies enable the multinational enterprises to operate almost freely in the regions of Nigeria. On the contrary, many challenges of the SMEs emphasized in literature hinder their competitive strength (Beck \& Demirguc, 2003; Ayozie, 2006). Akingunola (1995), Heller (2002), and Amatus (2007) proclaimed three ways by which SMEs face competition, the intra-competition, which is competition among the domestic organizations producing similar products, the inter-competition, which is competition between domestic firms and foreign multinational firms operating in the country, and competition between domestic firms and quality imported brands of products. Consequent upon the challenges enumerated above, the objectives being addressed by this study are: (1) to identify different types and intensity of competition that SMEs are exposed to along the life-cycle portfolio in Nigeria; (2) to quantify the strength of SMEs vis-à-vis some foreign enterprises in terms of market competition; and (3) to proffer solutions on how best they could match competitively these foreign enterprises. Ten each of juice-producing small and medium scale enterprises located at and around Ikeja Industrial Estate were studied for their privileged location. The significance of this study stemmed from the fact that SMEs will be empowered to stand and compete with other categories of organizations in the industries, hence emancipated to bring about better and gainful employment. There will be improvement in the standard of living of citizenry; and there will be growth and development of Nigeria's gross domestic product (GDP). Also local companies will be empowered technologically to exploit and extract natural deposits, hence engage capacity building to the Nigerian people.

\section{Literature Review and Hypotheses Development}

\section{Review of Definitional and Theoretical Issues}

Calson (2000), Krauss (2004), and Kerin, Hartley, Berkowitz, and Rudelins (2006) discussed competition as the fourth component of the environmental scan, that is, apart from social, economic, and technological forces, in which alternative firms could provide a product to satisfy a specific market needs. The authors enumerated four basic forms of competition at which one end of the continuum is pure competition. By pure competition, every company in the industry has and sells similar products. In the second point on the continuum is monopolistic competition where many sellers compete with their products on a substitutable basis. Oligopoly was given as the third component on the continuum, and the practice is that few companies control majority of the industry sales. The final point on the continuum was given as pure monopoly; in which only one firm sells the product. But Hunt and Duhan (2002) wrote on a multi-market competition which refers to competitive situations whereby same firms compete against each other in multiple markets. Both views above were supported by Adesina (2004) in Lagos, Nigeria, reviewing competition as an important part of industry development; and that developing country would be better off if fair competition is allowed to be introduced into them. Ries and Trout (2004) also contributing, claimed competition in marketing to be getting brutal; that the name of the game has become "taking business away from somebody else". For any business organization developing a marketing programme, four components that drive competition need to be considered. They are 
entry, bargaining power of buyers and suppliers, existing rivalries, and substitution possibilities. Porter (2008) in Figure 1 describes a concept that has become known as the "five forces model". This concept involves a relationship between competitors within an industry, potential competitors, suppliers, buyers, and alternative solutions to the problem being addressed.

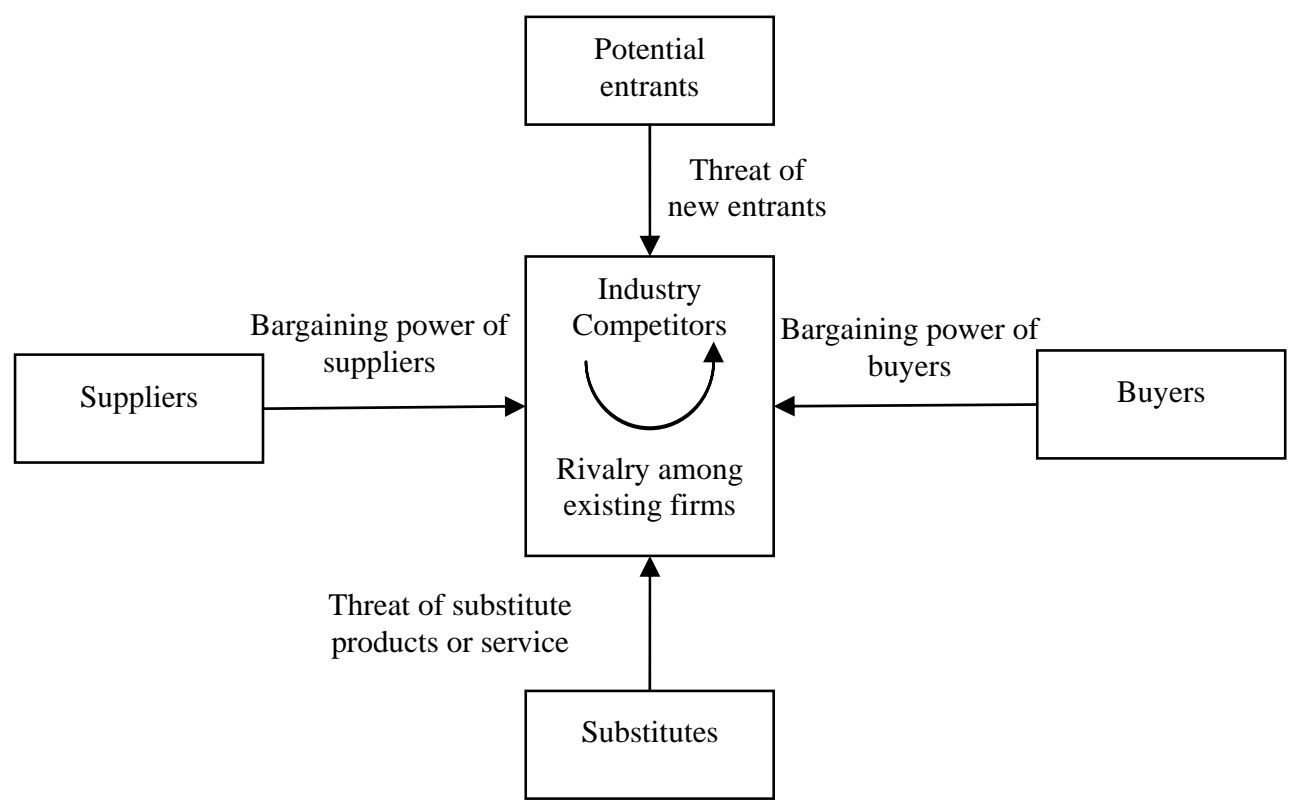

Figure 1. "Five forces model” of competition. Source: Porter (2008).

Literature reveals that while a small or medium scale business entrepreneur or a micro group in an industry is struggling to push his or her product(s) within the potential 10 key areas of the model, the relational strengths, in terms of market penetration, to a multinational enterprise is very low (Lester \& Tran, 2008). Organisation and management research uses the life-cycle concept to explain changes that take place in organisations. Most of these changes are caused by company's growth and management practices becoming more complex. The most comprehensive reviews of works on the life-cycle theory were given by Quinn and Cameron (1983), Smith, Mitchell, and Summer (1985), and Beverland (2001). It was noted that at each developmental stage of SMEs, the rate of competition faced aggravates (Schroeder \& Flynn, 2001; Mulford, 2004; Lester \& Tran, 2008). Figure 2 denotes developmental stages of SMEs, according to Eggers, Leahy, and Churchill (1994) and Shirokova (2009).

It is obvious from literature that all the authors recognized that there seems to be a life-cycle for firms similar to the classic product life-cycle approach. While researchers seriously differed in their opinions on the number of stages and characteristics to describe them, some authors offered generalized models which help to describe and make comparative analysis of different approaches. For instance, Hanks, Watson, Jansen, and Chandler (1993) offered a five-stage life-cycle model including foundation, expansion, maturity, diversification, and decline; others may contain four stages as establishment, growth, maturity, and decline (Gupta \& Chin, 1994) or even three, that is start-up, rapid growth, and maturity. Research in this direction has been inconclusive in the last few years. However, since the focus of this study is on survival of SMEs, three-stage life-cycle model was adopted with the effects of competition along their life-cycle. 


\begin{tabular}{|c|c|c|c|c|c|c|}
\hline \multicolumn{7}{|c|}{ Characteristics of Small Business at Each Stage of Development } \\
\hline & Stage I & Stage II & Stage III-D & Stage III-G & Stage IV & Stage V \\
\hline & Existence & Survival & $\begin{array}{l}\text { Success- } \\
\text { Disengagement }\end{array}$ & $\begin{array}{l}\text { Success- } \\
\text { Growth }\end{array}$ & Take-off & Resource Maturity \\
\hline $\begin{array}{l}\text { Management } \\
\text { style }\end{array}$ & $\begin{array}{l}\text { Direct } \\
\text { supervision }\end{array}$ & $\begin{array}{l}\text { Supervised } \\
\text { supervision }\end{array}$ & Functional & Functional & Divisional & Line and staff \\
\hline Organization & & & & & & \\
\hline $\begin{array}{l}\text { Extent of formal } \\
\text { systems }\end{array}$ & $\begin{array}{l}\text { Minimal to } \\
\text { nonexistent }\end{array}$ & Minimal & Basic & Developing & Maturing & Extensive \\
\hline Major strategy & Existence & Survival & $\begin{array}{l}\text { Maintaining } \\
\text { profitable } \\
\text { status quo }\end{array}$ & $\begin{array}{l}\text { Get resources } \\
\text { for growth }\end{array}$ & Growth & $\begin{array}{l}\text { Return on } \\
\text { investment }\end{array}$ \\
\hline $\begin{array}{l}\text { Business and } \\
\text { owner }^{*}\end{array}$ & & & & & & \\
\hline imaller & 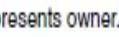 & & & & & \\
\hline
\end{tabular}

Figure 2. Stages of small business growth characteristics. Source: Egger et al. (1994).

\section{Effects of Competition on Firms' Life-Cycle}

Kolvereid (1992), Kolvereid and Bullvag (1996) asserted that the start-up stage of SMEs does not bother much about competition or the intensity of competition in the industry, rather, the entrepreneur, more or less, concentrates on satisfying consumers in the immediate environment, or adopts niche programmes to keep the young business going. At the growth stage, the authors claimed that entrepreneurs of SMEs start to see competition and its effects as impediments on their approaches, growths, and strategies. Mitra and Pingali (1999) in their study wrote how entrepreneurs spend quality time, efforts, and money on gathering information on competing brands, intensify efforts on distribution channels, vote some funds for products' promotion, while the level of the staff training and public relations is stepped up. Though Noel (2009) quoted experts that majority of small businesses fold up after an average of 18 months due to failure to stand up to competition, it is however found out that at maturity stage, operators of SMEs would have embraced a lot of facilities offered by the governments; including facilities from the industry's association. Hence, few of them tend to graduate to status of "followers" in some industries. In this dimension, they imitate what market leaders or challengers produce. At times, they adapt their brands in order to attract further patronage while still pushing the niche business (Fullerton, Dodge, \& Robbins, 1994). Fullerton, Dodge, and Robbins (1994) did not entirely agree on stages of organizational life-cycle as described in the literature for most small businesses. They are of the opinion that small businesses adapt and change in order to survive rather than grow. They identified competition as the dominant factor that impedes growth in small businesses.

In Figure 3, there are five stages of business evolution and five characteristics that define each stage. 
According to Egger et al. (1994), businesses with DNA that are suited to the environment and are competitive are "rewarded" by the sheer pleasure of reaching the next stage of the evolution. Those small businesses, in their evolutionary journey, that are not suited and not adaptable to the environment, and are not competitive in an industry segment are "discarded". The authors claimed that only the strong ones survive the competitive nature of the environment.

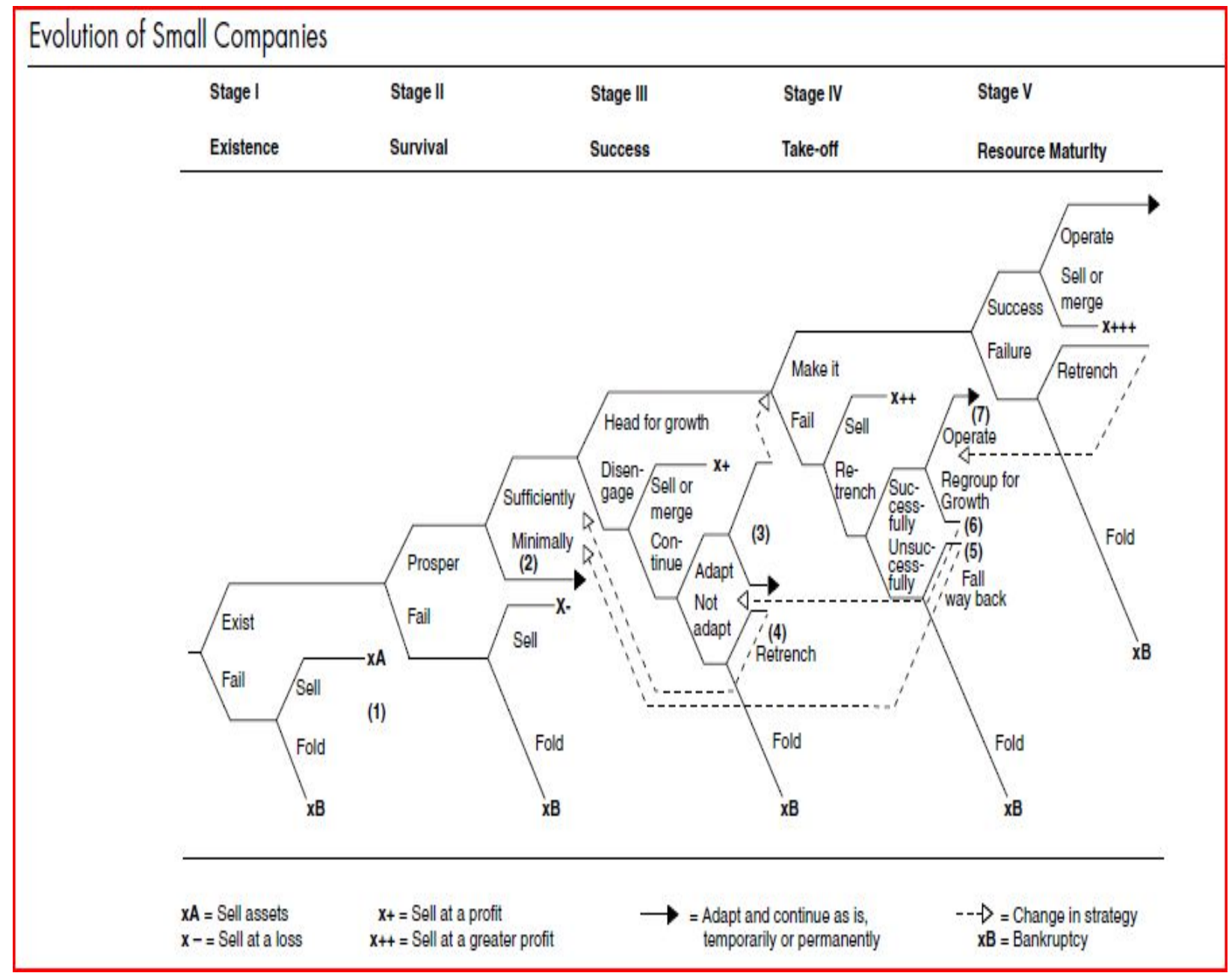

Figure 3. The diagram above depicts the framework evolution stages and failure \& exit modes. Source: Egger et al. (1994).

\section{Supporting Theories of Competition}

Hunt (1996) essentially challenged "managers" and "practitioners" to engage in the discussion of competition based on what develops as "resource-advantage". He canvassed that comparative advantages in resources can lead to marketplace positions of competitive advantage, which then lead to a superior performance. The fundamental premise of this theory is that the equilibrium-based analysis of much mainstream economics actually eliminates both the heterogeneity and dynamism that marks real-world industrial competition. Instead, resources of an organization should be viewed as heterogeneous and imperfectly mobile, and intra-industry demand is substantially heterogeneous. Kovatcheva and Kozerawska (2000) claimed that resource-advantage theory is an interdisciplinary, synthetic theory, and it is based on 
several economic traditions. Contrasted with the neoclassical tradition's view that firms are time-independent, mathematical abstractions that combine homogeneous, and perfectly mobile resources, the resource-based view posits that firms are entities that are (1) historically situated in space and time; (2) combine heterogeneous imperfectly mobile resources. Also, it draws on marketing's heterogeneous demand theory, which holds that, because intra-industry demand is significantly heterogeneous, different market offerings are required for different market segments in the same industry; and (3) it draws on industrial-organization economics and differential advantage theory, which hold that marketplace positions of competitive advantage (or disadvantage) determine superior (or inferior) financial performance. Fourth, it draws on evolutionary economics, which views competition as a selection process, a struggle that produces innovation. Fifth, it draws on "Austrian" economics, which stresses the importance of processes, entrepreneurship, and economic institutions. Because information is dispersed and tacit in the process of competitive rivalry, competition results in knowledge-discovery. Sixth, it draws on economic sociology and institutional economics, which hold that societal institutions, such as laws, customs, taboos, traditions, and moral codes, produce order by structuring political, economic, and social interaction. The kind of order so produced influences the process of competition and, thereby, such outcomes as productivity and economic growth are feasible. The foundational premises of resource-advantage theory are more descriptive of reality compared to preceding theories of competition. In addition, the resource-advantage theory concentrates on the importance of market segments and comparative advantage (disadvantage) in resources as well as on competitive advantage (disadvantage) in marketplace positions. Market segments represent, according to this theory, intra-industry groups whose tastes are relatively homogenous. Resources are defined as a firm's tangible and intangible entities that enable it to produce efficiently and effectively a market product, which has value to the certain market groups. Resources of firms are significantly heterogeneous and relatively immobile and thus some firms will have a comparative advantage and others comparative disadvantage. The firms are divided into nine types according to their market positions. In Figure 4, cells 2, 3, and 6 are positions of competitive advantage. That advantage is achieved through a relatively better combination of resource efficiency and produced value than that of competitors. The measure of competitive advantage is the firm's superior financial performance.

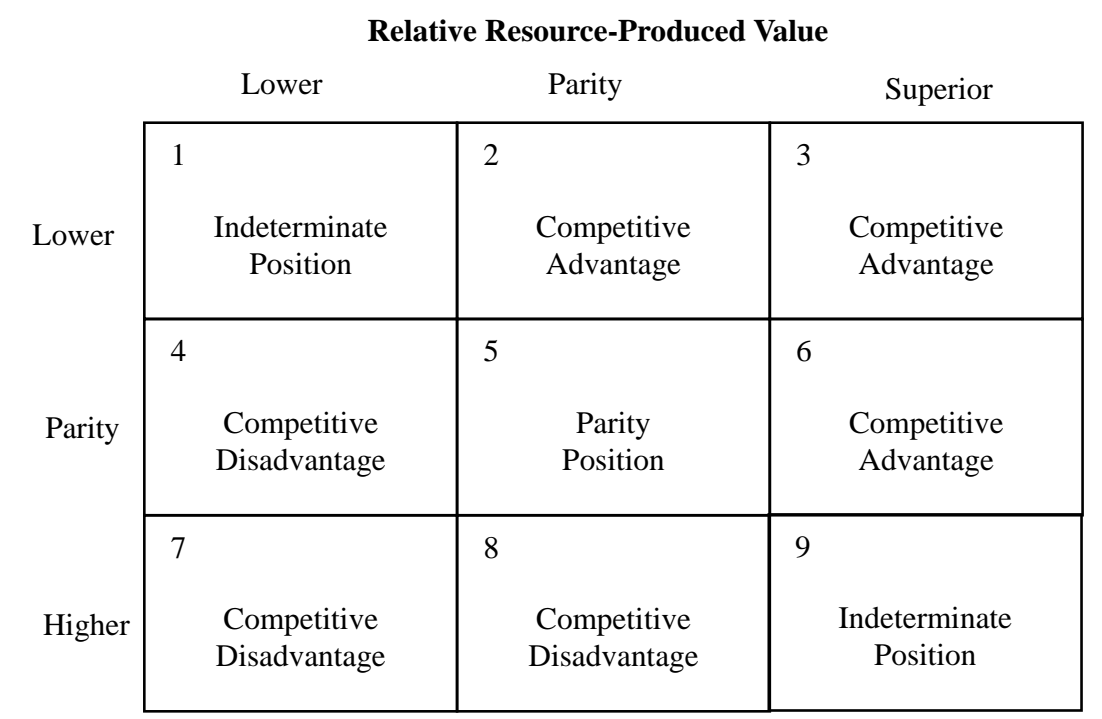

Figure 4. Relative resource-produced value. Source: Kovatcheva and Kozerawska (2000). 
The very competition in resource-advantage theory is defined as the disequilibrating on-going process that consists of the constant struggle among firms for competitive advantages. The nature of competition is influenced by five environmental factors: the societal resources, the societal institutions, actions of competitors and suppliers, behaviours of consumers, and public policy. Companies learn in that process trying to improve their financial performance, which is an indication of their market position, resulting from the competitive advantage (disadvantage) they achieve.

Hunt and Morgan (1995), on the one hand, offered an interesting and provocative essay. They observed three types of strand in recent research in marketing: The first gravitates toward competitive strategy, the second advocates market orientation for superior firm performance, and the third explores shifting values in the wake of emergent structural forms, such as alliances and networks. Hunt and Morgan (1995) asserted that the "strategy debate" in marketing has been evolving toward a new theory of competition in place of the dominant neoclassical theory of perfect competition (NTPC), which has retained its status despite many deficiencies. To address the limitations of the dominant perspective, they proposed the comparative advantage theory of competition (CATC). Using comparative advantage theory of competition, they explained the abundance, an admirable quality, and innovativeness of goods and services in market-based economies. In addition, they aimed to account for the presence of firm diversity in such economies. Accordingly, they attempted to consolidate a theory in the exchange paradigm tradition with an eclectic approach. In particular, they drew attention to the consensus on relating firm performance to the firm's special competencies in deploying and combining intangible assets. In contrast to the neoclassical theory of perfect competition, the comparative advantage theory of competition accentuates intangible aspects, such as organizational climate, as more specific to the firm and therefore treated them as more significant performance enhancers. The comparative advantage theory of competition warns us that if change, uncertainty, disequilibria, and institutional complexity are important parts of the picture, then some implications derived from the exchange paradigm theories must be viewed carefully. The authors' contribution was important in several respects. First, it raises sensitivity to epistemic issues in marketing (Peter, 1995; Hodgson, 2000; Savitt, 2000). Second, it provides an opportunity to rethink the bridge between marketing and economic theories. Third, by challenging the dominant perspective, it opens the door for the development of fresh views on competitive behaviour.

Hunt and Duhan (2002), on the other hand, propounded the theory of multimarket competition; suggesting that the phenomenon of mutual forbearance may reduce the market-level intensity of competition between two firms when the multimarket contact between them (the number of markets in which they compete) increases. Mutual forbearance, a form of tacit collusion in which firms avoid competitive attacks against those rivals they meet in multiple markets, is proposed to occur because multimarket competition increases the familiarity between firms and their ability to deter each other. In this article, the authors examine how multimarket contact increases familiarity and deterrence. Furthermore, they provide an extension of the theory of multimarket competition by developing a conceptual model that identifies competitive and market factors that moderate the relationship between the degree of multimarket contact and the intensity of competition. The authors also examine the implications of multimarket competition for marketing strategy in the context of two marketing strategy issues: product line rivalry and entry strategy. From the review of literatures above, the following two hypotheses were formulated for testing and substantiating based on null hypothesis: 
(1) $\mathrm{H}_{0}$ : Survival of juice-producing SMEs does not have a relationship with any form of competition on a firm's life-cycle.

(2) $\mathrm{H}_{0}$ : Competition does not have positive effects on survival components for juice-producing SMEs in Nigeria.

\section{Methodology}

Both survey and observation methods were used with a well structured questionnaire to elicit information from workers or staffs of SMEs producing juice-drinks. Cluster sampling was used to choose 20 prominent Ikeja based SMEs by dividing the Lagos finite SMEs population into mutually exclusive clusters, that is, Ikeja, Lagos Island, Lagos Mainland/Surulere, Badagry, Epe, and Ikorodu. Two research administrators holding Ordinary National Diploma in Business Administration were engaged for two weeks to support the effort of the researcher. They were trained on the assignment and fairly gainfully rewarded, 660 copies of the questionnaire were administered on a 50:50 ratio basis to the two categories of the enterprise, 474 copies of the questionnaire, representing $71.8 \%$ were returned, 276 copies, representing $83.6 \%$ were returned by staffs of small scale enterprises while 269 copies, representing 97.5\% were eventually used, seven (2.5\%) copies were rejected due to improper filling. On the other hand, 198 copies of the questionnaire representing $60 \%$ were returned by staffs of medium scale enterprises, 192 (97\%) copies could only be utilized, as six (3\%) copies had to be rejected. In all, 461 (69.85\%) respondents had their views utilized for the study, 5-points Likert summated rating scale was adopted. Also Yard's formula with 95\% confidence level and 5\% error tolerance was used. Internal consistency implied a high degree of generalization across the items within the measurement. Alternative form validity of the instrument was measured at 0.63 while its reliability was measured at Cronbach's alpha of 0.70 . Pearson's product-moment correlation was used in testing the stated hypothesis 1 while standard multiple regressions were used to test the stated hypothesis 2. Competition, as a dependent variable $(Y)$, was operationalized to contain pure, monopolistic, oligopoly, pure monopoly, and multimarket types of competition as components. Survival, as an independent variable $(X)$, was operationalized with sales revenue (Sr), profit (Pr), return on investment (ROI), lower cost (Lc), and loyalty (Loy) as components.

\section{Discussion of the Findings: Theoretical and Empirical}

Of the 461 copies of the questionnaire used, 258 (56\%) respondents were male staff, while 203 (44\%) were female staff of SMEs producing juice-drinks.

Four hundred and fifty-two (98\%) respondents expressed the view that juice products of SMEs sold better under pure competition situation than any form of competition, while $9(2.0 \%)$ respondents were undecided.

Three hundred and five (66.2\%) respondents strongly agreed, 125 (27.1\%) agreed, and 28 (6.1\%) were undecided while only three $(0.6 \%)$ disagreed with the view that SMEs would have done better in market places if they could have substitute brands of juice products to market.

Four hundred and one (87.0\%) respondents strongly agreed, 55 (11.9\%) agreed, and 5 (1.1\%) were undecided on the views that majority of SMEs did not have what it takes to control the industry's sales.

All, 461 (100\%) respondents agreed that no small or medium enterprise has been able to dominate sales of the industry's products.

All, 461 (100\%) respondents agreed that juice-drinks producing SMEs would have been able to sell and dominate markets, local and foreign, but for their low productivity. 
Two hundred and eighty-eight (62.5\%) respondents strongly agreed, 116 (25.2\%) agreed, 31 (6.7\%) were undecided, and 20 (4.3\%) disagreed, while six (1.3\%) strongly disagreed that same category of SMEs compete against each other in multiple markets.

Three hundred and thirty-seven (73.1\%) respondents strongly agreed, 117(25.4\%) agreed, and two (0.4\%) were undecided while only five (1.1\%) strongly disagreed with the view that products of SMEs compete with some products from multinational enterprises on the start-up stage of firms' life-cycle in Nigerian markets.

Twenty-six (4.1\%) respondents strongly agreed, 19 (17.0\%) agreed, 11 (2.7\%) were undecided, and 233 (42.5\%) disagreed while 172 (33.7\%) strongly disagreed that intensive rate of competition does not affect the productivity of SMEs at the growth stage of firms' life-cycle.

Eight (1.7\%) respondents strongly agreed, 13 (2.8\%) agreed, four (0.9\%) were undecided, and 192 (41.7\%) disagreed while 244 (52.9\%) strongly disagreed that very insignificant number of juice-producing SMEs outlive maturity stage of firms' life-cycle.

Four hundred and forty-seven (98\%) respondents strongly agreed expressly, while 14 (2.0\%) agreed the view that orientations and training in management and marketing practices will endow SMEs the skill to effectively manage any form of competition in juice segments of Nigerian market.

\section{Testing of Hypotheses}

\section{Hypothesis 1}

$\mathrm{H}_{\mathrm{o}}$ : Survival of juice-producing SMEs does not have a relationship with forms of competition on a firm's life-cycle.

In order to test for the relationship between survival of juice-producing SMEs and forms of competition on firm's life-cycle, Pearson's product-moment correlation was used. Pure, monopolistic, oligopoly, pure monopoly, and multimarket types of competition are components of competition, as a dependent variable (Y). Also, Sr, Pr, ROI, Lc, and Loy are components of survival, as an independent variable $(X)$.

From Table 1, for the 20 items represented in the questionnaire, the mean and the standard deviation for competition were 2.2715 and 2.1968; while the mean and standard deviation for survival of SMEs were 0.4849 and 0.4719 . These signified close relationship between competition and survival variables of the study.

Table 1

Descriptive Statistics

\begin{tabular}{llll}
\hline & Mean & Std. deviation & $N$ \\
\hline CIM & 2.2715 & 0.48488 & 461 \\
SSMEs & 2.1968 & 0.47189 & 461 \\
\hline
\end{tabular}

Note. Source: field survey, 2010.

Tables 2 reveals a significant relationship between the dependent and independent variables, and it corroborates the result of the descriptive statistics on Table 1; as the combined components of competition and survival variables had correlation coefficient of ( $r=0.931, n=461, p=0.01)$ each. Therefore, the correlative relationship that existed between the dependent variable, that is competition, and the independent variable, that is survival of SMEs indicated that the null hypothesis will not be accepted but the alternative hypothesis accepted. The null hypothesis suggested no relationship between the dependent competition and independent survival variables on firm's life-cycle. It was found out that there was strong relationship between the two; 
hence survival of juice-producing SMEs had relationship with forms of competition on a firm's life-cycle. Corroborating the findings, O'Farrell and Hichens (1988) argued that most small business models place little or no emphasis on external factors that influence greatly the sustainability of the firm such as meeting competition in the market place. Rather, most efforts in developing strategies against competition for the small business focus on internal dynamics of the firm. The authors showed that changes within an organization follow a predictable pattern characterized at development stages as follows: The sequence of events that describes how things change over time; the hierarchical progression that is not easily reversed; and finally, the composite of a broad range of organizational activities and structures. Firms in their empirical study had fewer management and financial problems, but more marketing problems, as they progressed from stage to stage. Fullerton, Dodge, and Robbins (1994) did not entirely agree on stages of organizational life-cycle as described in the literature for most small businesses. They are of the opinion that small businesses adapt and change in order to survive rather than grow. They identified competition as the dominant factor that impedes growth in small businesses.

Table 2

Correlations

\begin{tabular}{lcll}
\hline & & CIM & SSMEs \\
\hline CIM & Pearson correlation & 1 & $0.931\left(^{* *}\right)$ \\
& Sig. (2-tailed) & 461 & 0.000 \\
\multirow{2}{*}{ SSMEs } & $N$ & $0.931\left(^{* *}\right)$ & 461 \\
& Pearson correlation & 0.000 & 1 \\
& Sig. (2-tailed) & 461 & 461 \\
\hline
\end{tabular}

Notes. $^{* * *}$ Correlation is significant at the 0.01 level (2-tailed). Source: field survey, 2010.

\section{Testing of Hypothesis 2}

$\mathrm{H}_{0}$ : Competition does not have positive effects on survival components for juice-producing SMEs in Nigeria.

In testing this hypothesis, the multiple regressions were used to know whether competition has positive effects on survival components for juice-producing SMEs in Nigeria.

Table 3 shows the mean and standard deviation statistics of the independent and dependent variables of hypothesis 2.

Table 3

Descriptive Statistics

\begin{tabular}{llll}
\hline & Mean & Std. deviation & $N$ \\
\hline SSMEs & 2.1968 & 0.47189 & 461 \\
Sr & 1.9747 & 0.57956 & 461 \\
Pr & 2.4335 & 0.74648 & 461 \\
ROI & 2.5696 & 0.92934 & 461 \\
Lc & 2.2278 & 0.66409 & 461 \\
Loy & 2.1519 & 0.79403 & 461 \\
\hline
\end{tabular}

Note. Source: field survey, 2010.

The correlation Table 4 reveals that there were statistically significant relationships between the dependent variable and the independent variable. With a coefficient of 0.765 , the strongest relationship was between sales revenue and survival of SMEs, while the lowest correlation was that of loyalty and survival of SMEs with coefficient of 0.419 . 
Table 4

\section{Correlations}

\begin{tabular}{|c|c|c|c|c|c|c|c|}
\hline Variables & & SSMEs & $\mathrm{Sr}$ & $\mathrm{Pr}$ & ROI & Lc & Loy \\
\hline & & 1.000 & 0.765 & 0.754 & 0.646 & 0.477 & 0.419 \\
\hline Pearson correlation & SSMES & 0.765 & 1.000 & 0.392 & 0.215 & 0.240 & 0.144 \\
\hline $\mathrm{Sr}$ & & 0.754 & 0.392 & 1.000 & 0.420 & 0.199 & 0.198 \\
\hline $\begin{array}{l}\mathrm{Pr} \\
\mathrm{POI}\end{array}$ & & 0.646 & 0.215 & 0.420 & 1.000 & 0.374 & 0.342 \\
\hline RUI & & 0.477 & 0.240 & 0.199 & 0.374 & 1.000 & 0.171 \\
\hline Lc & & 0.419 & 0.144 & 0.198 & 0.342 & 0.171 & 1.000 \\
\hline $\begin{array}{l}\text { Loy } \\
\text { Sig \{1-tailed }\}\end{array}$ & SSMES & & 0.000 & 0.000 & 0.000 & 0.000 & 0.000 \\
\hline $\begin{array}{l}\text { Sig. }\{1 \text {-talled }\} \\
\text { Sr }\end{array}$ & SSIVILS & 0.000 & . & 0.000 & 0.029 & 0.017 & 0.102 \\
\hline $\begin{array}{l}\mathrm{SI} \\
\mathrm{Pr}\end{array}$ & & 0.000 & 0.000 & . & 0.000 & 0.039 & 0.040 \\
\hline ROI & & 0.000 & 0.029 & 0.000 & 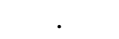 & 0.000 & 0.001 \\
\hline Lc & & 0.000 & 0.017 & 0.039 & 0.000 & . & 0.066 \\
\hline $\begin{array}{l}\text { Le } \\
\text { Loy }\end{array}$ & & 0.000 & 0.102 & 0.040 & 0.001 & 0.066 & \\
\hline $\begin{array}{l}\text { LUy } \\
\text { NSSMEs }\end{array}$ & & 461 & 461 & 461 & 461 & 461 & 461 \\
\hline $\mathrm{Sr}$ & & 461 & 461 & 461 & 461 & 461 & 461 \\
\hline $\begin{array}{l}\mathrm{SI} \\
\mathrm{Pr}\end{array}$ & & 461 & 461 & 461 & 461 & 461 & 461 \\
\hline $\begin{array}{l}\text { Pr } \\
\text { ROI }\end{array}$ & & 461 & 461 & 461 & 461 & 461 & 461 \\
\hline LC & & 461 & 461 & 461 & 461 & 461 & 461 \\
\hline $\begin{array}{l}\text { LC } \\
\text { Loy }\end{array}$ & & 461 & 461 & 461 & 461 & 461 & 461 \\
\hline
\end{tabular}

Note. Source: field survey, 2010.

Table 5 shows a model summary of how much of variance in the dependent variable (competition) was expressed by the independent variables (survival of SMEs). The adjusted $R$ Square value, when transformed indicated a 98.2\% level of variance in survival of juice-producing SMEs, while the standard error was less than $1 \%$. The interpretation of this model is that competition has positive effects on survival components for juice-producing SMEs in Nigeria.

Table 5

Model Summary

\begin{tabular}{lllll}
\hline Model & $R$ & $R$ Square & Adjusted $R$ Square & Std. error of the estimate \\
\hline 1 & 0.991 (a) & 0.982 & 0.980 & 0.06610 \\
\hline
\end{tabular}

Notes. (a) Predictors: (constant), Sr, Pr, ROI, Lc, Loy. Source: field survey, 2010.

Table 6 shows a significance of 0.000 which implied a high or perfect significance. Hence, the alternative hypothesis shall be accepted and the null hypothesis will be rejected.

Table 6

Anova

\begin{tabular}{llrlll}
\hline Model & Sum of squares & $d f$ & Mean square & $F$ & Sig. \\
\hline 1 Regression & 17.050 & 5 & 3.410 & & \\
Residual & 1.82 & 455 & 0.004 & 780.402 & 0.000 (a) \\
Total & 18.870 & 460 & & & \\
\hline
\end{tabular}

Notes. (a) Predictors: (constant), Sr, Pr, ROI, Lc, Loy. Source: field survey, 2010.

Table 7 shows which of the variables included in the model contributed to the determination of the dependent variable. In this case, beta values in the coefficient table were used for evaluation since the study was interested in comparing the role of each independent variable. It should be noted that the B values in the table are the coefficients of the independent variables. As a result, the equation of the model will be as follow: 
$y=0.15+0.405(\mathrm{Sr})+0.244(\mathrm{Pr})+0.136(\mathrm{ROI})+0.110(\mathrm{Lc})+0.091$ (Loy) where each letter stands as specified earlier. It should however be noted that 0.015 represented a constant as calculated statistically. The highest beta coefficient is 0.497 which represented sales revenue. This meant that sales revenue was a very strong contributor to survival of SMEs, 0.153 which represents loyalty has the least contribution to competition, a dependent variable. This however, does not mean that there was no significant and direct relationship as it does not reflect a negative figure with the "-” sign. All the independent variables used in the research work were found to be significant even as the Sig. column shows 0.000 all through. Sales revenue emerged as having the strongest contribution to competition, followed by profit with the beta coefficient of 0.386 and then ROI with the Beta coefficient of 0.267 , less cost component with Beta coefficient of 0.115 , and loyalty component with Beta coefficient of 0.153 .

Table 7

Coefficients

\begin{tabular}{llllrl}
\hline \multirow{2}{*}{ Model } & \multicolumn{2}{l}{ Unstandardized coefficients } & Standardized coefficients & $t$ & Sig. \\
\cline { 2 - 6 } & $\mathrm{B}$ & Std. error & Beta & $\mathrm{B}$ & Std. error \\
\hline 1 (constant) & 0.015 & 0.038 & & 0.396 & 0.693 \\
Sr & 0.405 & 0.014 & 0.497 & 28.303 & 0.000 \\
Pr & 0.244 & 0.012 & 0.386 & 20.750 & 0.000 \\
ROI & 0.136 & 0.010 & 0.267 & 13.928 & 0.000 \\
Lcp & 0.110 & 0.012 & 0.155 & 8.919 & 0.000 \\
Loy & 0.091 & 0.010 & 0.153 & 9.004 & 0.000 \\
\hline
\end{tabular}

Note. Source: field survey, 2010.

Also looking at the Sig. coefficient column, all the independent variables had significant level with a coefficient of 0.000 indicating that all the variables were equally important with respect to competition. Thus, since all the independent variables have a statistical significance (effects) with respect to competition, we rejected the null hypothesis which says that competition does not have positive effects on survival components for juice-producing SMEs in Nigeria, and accepted the alternative view that competition has positive effects on survival components for SMEs in Nigeria. The regression analysis however gave an equation for the model in order to predict the gravity of competition which was outside the scope of this study. Andretsch, Clarysse, and Duchene (2000) expressed, at a Conference of Ministers responsible for SMEs, the ability of SMEs to create, access, and commercialize new knowledge on global markets to be fundamental to their sustained competitiveness. The survival moves identified some principle strategies SMEs have pursued on their own, which included: the innovation strategy, in which SMEs try to appropriate returns from their knowledge base (which may or may not involve own investments in research and development). The information technology strategy makes innovative uses of information technology, in order to reduce enterprises' costs and increase productivity. The niche strategy is chosen by the enterprises to become sophisticated global players in a arrow product line. The network strategy, in which SMEs work co-operates with other firms, be they SMEs or large enterprises, in order to improve their ability to access and absorb innovations. The cluster strategy, in which SMEs locate in close proximity with competitors in order to take advantage of knowledge spill-over's, especially in the early stages of the industrial life-cycle. However, Andretsch, Clarysse, and Duchene (2000) emphasized that both scale economies and research and development have become more important instruments for competitiveness in the global economy. Since SMEs seem to be at a disadvantage for both these factors, many experts predicted their demise in terms of competitiveness as globalization increases. While many SMEs have 
indeed succumbed to a deterioration of competitiveness, others have found ways to actually enhance their positions in global markets. The actual record of the competitiveness of SMEs in the Organization of Economic Co-operation and Development (OECD) countries has been heterogeneous and complex due to their sheer numbers, which span a broad range of economic activities in a disparate set of industries across different countries.

\section{Concluding Remarks and Implications of the Study}

From this research, we can conclude that:

(1) From the findings, it was evident that competition subsists in any industry; not only in Nigeria, also globally and it bites hard in terms of loss of revenue, profits, and ROI on any business organization that does not have the strategies to support its operations;

(2) Every business organization goes through life-cycle. SMEs in Nigeria have to monitor and manage the rate at which competition affects their businesses positively and/or negatively;

(3) Operators of SMEs in Nigeria need to be trained to understand different forms of competition available so as to be able to determine the required strategies adoptable for survival of particular business enterprise;

(4) So far, majority of SMEs in Nigeria have businesses operating within pure and multimarket forms of competition. Nigerian governments should assist the operators, through their agents, to technologically tap agricultural and mineral resources which would give Nigerian entrepreneurs opportunity and privilege to produce goods that can operate on monopolistic, oligopoly, and pure monopoly forms of competition. By this, the dominant structure of the multinational enterprises in Nigerian industries will subside or reduce;

(5) Since competition is pre-requisite to survival of SMEs, Nigerian entrepreneurs should hold it as a "factor" among other factors of consideration during planning and operational stages of business;

(6) Consequently, there will be reduction in high mortality rate of SMEs in Nigeria, instead SMEs will grow and outlive the founding entrepreneurs.

\section{References}

Adesina, K. (2004). Competition is key in the market. Marketing Edge, 1(2), 24.

Akingunola, R. O. (1995). Financial of small and medium scale enterprises through equity sources. In A. T. Ojo (Ed.), Management of small and medium scale enterprises in Nigeria (pp. 87-94). Pumark Nigeria, Lagos.

Amatus, A. (2007). This man invented a formula for wealth creation. Daily Sun (p. 16).

Audretsch, D., Clarysse, B., \& Duchêne, V. (2000). Enhancing competitiveness of small and medium enterprises through innovation. Proceedings from the Conference of Ministers Responsible for Small and Medium Enterprises. Industry Ministers, Bologna, Italy.

Ayozie, O. D. (2006). The role of small scale industry in national development in Nigeria. Retrieved from http://www.scribd.com/doc/23665278/

Beck, T., \& Demirguc, K. (2003). Small and medium enterprises, growth and poverty. World Bank Public Policy For Private Sector, Note No. 268.

Beverland, M. (2001). Organizational life cycles in small New Zealand wineries. Journal of Small Business Management, 12(3), 5.

Calson, D. (2000). The old economy in the new economy. Business Week (p. 42H).

Eggers, J. H., Leahy, K. T., \& Churchill, N. C. (1994). Stages of small business growth revisited: Insights into growth path and leadership/management skills in low- and high-growth companies. Journal of Humanities, Psychology and Social Science, 5(4), 110-119.

Fullerton, S., Dodge, H., \& Robbins, J. (1994). Stage of the organizational life-cycle and competition as mediators of problem perception for small businesses. Strategic Management Journal, 15, 121-134. 
Gupta, Y. P., \& Chin, D. W. (1994). Organizational life-cycle: A review and proposed directions. The Mid-Atlantic Journal of Business, 4(3), 71-83.

Hanks, S., Watson, C., Jansen, E., \& Chandler, G. (1993). Tightening the life-cycle construct: A taxonomic study of growth stage configurations in high-technology organizations. Entrepreneurship Theory and Practice, 18(2), 5-19.

Heller, R. (2002). Assessing your entrepreneurship profile: Do you have what it takes? Business The Ultimate Resource TM, Bloomsbury Reference Book (pp. 818-819), London.

Hodgson, G. M. (2000). The marketing of wisdom: Resource-advantage theory. Journal of Macromarketing, 20(1), 16-27.

Hunt, S. D. (1996). The resource-advantage theory of competition: Dynamics, path dependencies, and evolutionary dimensions. Retrieved from http://www.jstor.org/stable/1251905

Hunt, S. D., \& Duhan, D. F. (2002). Competition in the third millenium: Efficiency or effectiveness? Journal of Business Research 55(2), 97-102.

Hunt, S. D., \& Morgan, R. M. (1995). The comparative advantage theory of competition. Journal of Marketing, 14(3), 1-12.

Kerin, R. A., Hartley, S. W., Berkowitz, E. N., \& Rudelins, W. (2006). Marketing (8th ed.). New York: McGraw-Hill.

Kolvereid, L. (1992). Growth aspirations among Norwegian entrepreneurs. Journal of Business Venturing, 7(3), 209-222.

Kolvereid, L., \& Bullvag, E. (1996). Growth intentions and actual growth: The impact of entrepreneurial choice. Journal of Enterprising Culture, 4(1), 1-17.

Kovatcheva, E., \& Kozerawska, A. (2000). Marketing of wisdom: Resource-advantage theory. Retrieved from http://www.pafis.shh.fi/ elikov02/Case_1/RAtheory.html

Krauss, M. (2004). Young net entrepreneurs leverage web anew. Marketing News (p. 4).

Lester, D. L., \& Tran, T. T. (2008). Organizational life-cycle and performance among small and medium enterprises: Generic strategies for high and low performers. International Journal of Commerce and Management, 1, 4-7.

Mitra, R., \& Pingali, V. (1999). Analysis of growth stages in small firms: A case study of automobile ancillaries in India. Journal of Small Business Management, 37(3), 43-61.

Mulford, B. (2004). Let all the competition eat their hearts out. Retrieved from http://www.sbynews.blogspot.com/2009/11/brooke-mulford-update_13.html

Noel, J. (2009). Small and medium enterprises' life-cycle: Steps to failure or success?. Retrieved from www.moyak.com/papers/small-medium-enterprises.pdf

O'Farrell, P. N., \& Hitchen, D. M. (1988). Alternative theories of small firms' growth: A critical review. Environmental and Planning, 20(2), 1365-1383.

Ogujiuba, K. K., Ohuche, F. K., \& Adenuga, A. O. (2004). Credit availability to small and medium scale enterprises in Nigeria: Importance of new capital base for banks. Background and Issues Bullion: Central Bank of Nigeria, 28(4), 57-68.

Ogundele, O. J. K. (2007). Introduction to entrepreneurship development, corporate governance and small business management. Lagos: Molofin Nominees.

Ogundele, O. J. K., \& Opeifa, A. Z. (2004). The influence of external political environment on the processes of entrepreneurship. The Nigerian Academic Forum: A Multidisciplinary Journal, 7(5), 7.

Okaka, P. O. (1990). Entrepreneurship development programme in Kenya. Directorate of Technical Training and Applied Technology (pp. 8-10).

Peters, T. (1995). New products, new markets, new competition, new thinking. The Economist, 4, 27-32.

Porter, M. E. (2008). The five competitive forces that shape strategy. Harvard Business Review, 16, 86-87.

Quinn, R., \& Cameron, K. (1983). Organizational life cycles and shifting criteria of effectiveness: Some preliminary evidence. Management Science, 29(1), 33-51.

Ries, A., \& Trout, J. (2004). Marketing warfare. Retrieved from http://blogcritics.org/books/article/al-ries-jack-trout-marketing-warfare/\#ixzz2MSh5FsCn

Savitt, R. (2000). A philosophical essay about a general theory of competition: Resources, competencies, productivity, economic growth. Journal of Macromarketing, 20(1), 73-76.

Schroeder, R. G., \& Flynn, B. B. (2001). High performance manufacturing: Global perspectives. Retrieved from http://books.google.com.ng/books?id=XWrt4dN7U5IC\&pg=PA278\&l

Shirokova, G. (2009). Organizational life-cycle: The characteristics of developmental stages in Russian companies. Journal for East European Management Studies, 14(1). 65-85.

Smith, K., Mitchell, T., \& Summer, C. (1985). Top level management priorities in different stages of the organizational life cycle. Academy of Management Journal, 28(4), 799-820. 